\title{
Gambaran Karakteristik Pasien dan Mekanisme Pemberian Vaksin Anti Rabies (VAR) Pada Kasus Gigitan Hewan di RSPI Prof. Dr. Sulianti Saroso Tahun 2014-2016
}

\author{
Description of Patient Characteristics and Mechanisms of Giving Anti Rabies Vaccines \\ (VAR) in Animal Bits Case in RSPI Prof. Dr. Sulianti Saroso 2014-2016
}

\author{
Wariyah*, Jamiatul Hoer, Farah Ghina Arifah, Siti Maemun, Farida Murtiani, Nursanti \\ Kurniastuti
}

Rumah Sakit Penyakit Infeksi Prof. Dr. Sulianti Saroso

\author{
*Korespodensi : \\ Wariyah \\ Email: rialawole6363@gmail.com
}

\begin{abstract}
Abstrak
Latar Belakang : rabies adalah suatu penyakit infeksi akut pada susunan saraf pusat yang disebabkan oleh virus rabies yang dapat ditularkan dari hewan ke manusia melalui gigitan hewan penular rabies (GHPR). Rabies berakibat fatal jika post-exposure prophylaxis (PEP) tidak diberikan sebelum pasien mengalami gejala berat. Tujuan kajian ini memperoleh gambaran karakteristik pasien dan mekanime pemberian vaksin anti rabies (VAR) pada pasien GHPR di RSPI Prof. Dr. Sulianti Saroso tahun 20142016. Metode : kajian menggunakan desain studi deskriptif dengan pendekatan kuantitatif terhadap data rekam medis pasien suspect rabies. Jumlah sampel yang diperoleh sesuai kriteria inklusi sejumlah 39 kasus yang diambil secara random. Hasil : Karakteristik pasien mayoritas perempuan 203 kasus (51.39\%), kelompok umur dewasa 213 kasus (53.92\%), tidak bekerja 251 kasus (63.54\%) dan berdomisili di DKI Jakarta 337 kasus (85.32\%). Kelompok gigitan hewan sebagian besar adalah kelompok hewan penular rabies (HPR) 341 kasus (86.3\%) dengan kriteria luka gigitan kategori luka 2 sebanyak 275 kasus (69.6\%), dan di area kaki sebanyak 172 kasus (43.54\%), mendapatkan PEP awal dalam waktu $\leq 24$ jam 329 kasus (83.3\%) dan menyelesaikan jadwal PEP hingga kunjungan VAR 3 sebesar183 kasus (46,33\%). Kesimpulan : Dari 395 kasus sebagian besar kasus HPR dengan luka gigitan kategori 2 dengan lokasi gigitan di kaki, pemberian PEP $\leq 24$ jam dan menyelesaikan hingga kunjuangan VAR 3.
\end{abstract}

Kata kunci : Rabies, Vaksin Anti Rabies

\begin{abstract}
Background : Rabies is an acute infectious disease in the central nervous system caused by the rabies virus which can be transmitted from animals to humans through the bite of rabies transmitting animals (GHPR). Rabies is fatal if post-exposure prophylaxis (PEP) is not given before the patient experiences severe symptoms. The Objective to obtain an overview of patient characteristics and the mechanism of administration of the anti-rabies vaccine (VAR) in GHPR patients at RSPI Prof. Dr. Sulianti Saroso in 20142016. Method : the study used a descriptive study design with a quantitative approach to the patient's medical record data suspect rabies with the specified criteria. The number of samples obtained according to the inclusion criteria was 395 cases taken randomly. Results : The majority of female patients were 203 cases (51.39\%), adult age groups were 213 cases (53.92\%), unemployment was 251 cases (63.54\%) and domiciled in DKI Jakarta were 337 cases (85.32\%). Most of the animal bite groups were rabies transmitting animal groups (HPR) of 341 cases (86.3\%) with the criteria of bite wounds in the wound category 2 as many as 275 cases (69.6\%), and in the foot area as many as 172 cases (43.54\%), getting the initial PEP in time $\leq 24$ hours 329 cases (83.3\%) and completing the PEP schedule until VAR 3 visits were 183 cases (46.33\%). Conclusion : Of the 395 cases most of the HPR cases were categorized as bite 2 with the location of the bite in the leg, given PEP <24 hours and completing until the VAR visit 3.
\end{abstract}

Keywords: Rabies, Anti Rabies Vaccine

The Indonesian Journal of Infectious Diseases | Volume 4 No. 2 


\section{Pendahuluan}

Rabies atau penyakit anjing gila adalah suatu penyakit infeksi akut pada susunan saraf pusat yang disebabkan oleh virus rabies. Penyakit ini bersifat zoonotik yaitu penyakit dapat ditularkan dari hewan ke manusia melalui gigitan hewan penular rabies (HPR). Virus rabies termasuk genus Lyssa-virus, famili Rhabdoviridae dan menginfeksi manusia melalui gigitan hewan terinfeksi (anjing, monyet, kucing, serigala, kelelawar). Rabies hamper selalu berakibat fatal jika post-exposure prophylaxis (PEP) tidak diberikan sebelum onset gejala berat. Virus rabies bergerak keotak melalui saraf perifer. Masa inkubasi dari penyakit ini tergantung pada seberapa jauh jarak perjalan virus untuk mencapai sistem saraf pusat, biasanya mengambil masa beberapa bulan. ${ }^{(1)}$

Rabies tersebar hampir disemua benua kecuali benua antartika, lebih dari 150 negara telah terjangkit penyakit ini. Organisasi Kesehatan Dunia (WHO) memperkirakanbahwa 99\% kasus rabies manusia ditularkan melalui gigitan anjing yang terinfeksi dan infeksi tersebut menyebabkan puluhan ribu kematian setiap tahunnya, terutama di Afrikadan Asia. Empat dari setiap 10 kematian akibat rabies ada pada anak-anak di bawah 15 tahun. Rabies diperkirakan menyebabkan setidaknya 55.000 kematian per tahun di seluruh dunia, sekitar $56 \%$ di antaranya terjadi di Asia dan 44\% di Afrika, terutama di daerah pedesaan pada kedua kejadian tersebut. ${ }^{(2)}$

Berdasarkan data Kemenkes, dalam 5 tahun terakhir (2011-2015) jumlah rata-rata kasus gigitan hewan penular rabies (GHPR) pertahun adalah 78.413 kasus dan rata-rata sebanyak 63.534 kasus mendapatkan Vaksin Anti Rabies (VAR).Profil Kesehatan Indonesia menyebutkan angka kasus di Indonesia pada tahun 2015 terdapat 80.433 kasus GHPR. Kasus GHPR paling banyak terjadi di Bali yaitu sebanyak 42.630 kasus, diikuti oleh NTT yaitu sebanyak 7.386 kasus. Sedangkan untuk kematian akibat rabies (Lyssa) terdapat 118 kasus, terjadi paling banyak di Sulawesi Utara sebanyak 28 kasus dan Bali sebanyak 15 kasus, sedangkanuntukprovinsi di Indonesia yang masihtetapbebas rabies yaitu Nusa Tenggara Barat, Papua, Papua Barat, Bangka Belitung, Riau, DKI Jakarta, DIY, Jawa Tengah dan JawaTimur. ${ }^{(3)}$

Rabies merupakan penyakit yang belum ada obatnya, tetapi dapat dicegah dengan jalan memberikan vaksinasi rabies. Pemberian Vaksin Anti Rabies (VAR) dalam waktu 10 hari infeksi yang dikenal sebagai postexposure prophylaxis atau "PEP". VAR 
secara intra musculer (IM) pada otot deltoid atau anterolateral paha dengan dosis $0,5 \mathrm{ml}$ pada hari $0,3,7,14,28$ (Regimen Essen atau rekomendasi WHO), atau pemberian VAR $0,5 \mathrm{ml}$ pada hari 0, 7, 21 (Regimen Zagreb/ rekomendasi Depkes RI). Jika dilakukan perawatan awal setelah digigit anjing pengidap rabies, seperti pencucian luka, pemberian VAR dan SAR, maka angka survival mencapai $100 \%$. $^{(4)}$

Pertimbangan dalam pemberian VAR atau kombinasi VAR dan SAR salah satunya ditentukan menurut kategori luka yaitu dosis VAR yang direkomendasikan adalah 0,5 ml Verorab (Purified Vero Rabies Vaccine) atau $1 \mathrm{ml}$ Rabipur (Purified Chick Embriyo Cell-culture) setiap penyuntikan, pemberian VAR pada manusia yang tergigit hewan tersangka rabies digunakan dengan metode 2-1-1 yaitu 2 dosis pada hari ke 0 (pada region deltoideus kiri dan kanan), 1 dosis hari ke 7 dan 1 dosisharike 21 secara intramuscular (IM). VAR disuntikan secara intramuscular (IM) di daerah lengan atas (deltoid) atau untuk anak $<1$ tahun diberikan pada pangkal paha (anterolateral). Namun, jika pasien mengalami gigitan ulangan dalam waktu kurang dari 3 bulan tidak perlu diberi VAR, 3-12 bulan diberi VAR 1 dosis, atau lebih dari 1 tahun diberi dosis lengkap sebagaimana kasus baru. ${ }^{(3,5,6)}$ Metode pemberian VAR yang digunakan di RSPI Prof. Dr. Sulianti Saroso ialah dengan metode Zagreb.

Data surveilans Bidang Epidemiologi Direktorat Pengkajian Penyakit Infeksi dan Penyakit Menular RSPI Prof. Dr. Sulianti Saroso data pasien IGD kasus GHPR adalah 1173 pada tahun 2014, 1574 pada tahun 2015, dan 1643 pada tahun 2016,dan14 total kasus rawat inap selama tahun 2014 sampai 2016. Dapat disimpulkan bahwa terjadi peningkatan kasus GHPR dalam tiga tahun terakhir. Hasil telusur dokumen laporan surveilans GHPR bulan Oktober tahun 2013 ada 20\% kasus GHPR tidak sesuai dalam pemberian VAR.

Berdasarkan penjelasan di atasmaka dilakukan kajian tentang "Gambaran Karakteristik dan Mekanisme Pemberian Vaksin Anti Rabies (VAR) Pada Pasien Gigitan Hewan Penular Rabies (GHPR) di Rumah Sakit Penyakit Infeksi Prof. Dr. Sulianti Saroso (RSPI SS) Tahun 2014 - 2016".

\section{Metode}

Kajian ini menggunakan desain studi deskriptif dengan pendekatan kuantitatif. Sampel dalam penelitian ini adalah data GHPR di RSPI Prof. Dr. Sulianti Saroso 2014-2016. Besar 
sampel dihitung dengan menggunakan rumus besar sampel pengujian hipotesis untuk satu sampel populasi presisi diperoleh sebanyak 395 sampel yang diambil dengan teknik simple random sampling. Peneliti mendapatkan sampling frame dari data surveilans GHPR tahun 2014-2016 kemudian dilakukan random menggunakan tabel. Setelah itu dilakukan penelusuran data rekam medik. Analisa data secara deskriptif berupa distribusi frekuensi.

\section{Hasil}

Karakteristik pasien kasus gigitan hewan di RSPI Prof. Dr. Sulianti Saroso dipaparkan pada tabel 1. Hasil menunjukkan jenis kelamin terbanyak ialah berjenis kelamin perempuan dengan mayoritas kelompok umurdewasa (18-60 tahun), tidak bekerja dan berdomisili di DKI Jakarta.

Kasus GHPR di RSPI Prof. Dr. Sulianti Saroso memiliki kriteria luka gigitan kategori luka 2 (Luka risiko rendah) sebesar 69,6\% dan gigitan di area kaki yaitu sebesar $43.54 \%$ (Tabel $3)$.

Berdasarkan pengelompokan gigitan hewan, sebagian besar pasien kasus gigitan hewan di RSPI Prof. Dr. Sulianti Saroso digigit oleh kelompok HPR jenis
Anjing, Kucing dan Kera (AKK) sebesar 86.3\%(Tabel 2).

Tabel 1. Karakteristik Demografi pasien kasus gigitan hewan di RSPI Prof. Dr. Sulianti Saroso

\begin{tabular}{|c|c|c|}
\hline Demografi & $\begin{array}{l}\text { frekuensi } \\
\text { (n) }\end{array}$ & $\%$ \\
\hline \multicolumn{3}{|l|}{ Jenis Kelamin } \\
\hline Laki-Laki & 192 & 48,61 \\
\hline Perempuan & 203 & 51,39 \\
\hline \multicolumn{3}{|l|}{ Kelompok Umur } \\
\hline Anak ( $\leq 18$ tahun) & 140 & \multirow{2}{*}{$\begin{array}{l}35,44 \\
53,92\end{array}$} \\
\hline Dewasa (> $18-\leq$ & 213 & \\
\hline Lansia ( $>60$ tahun) & 40 & 10,13 \\
\hline \multicolumn{3}{|l|}{ Pekerjaan } \\
\hline Nelayan & 1 & 0,25 \\
\hline Buruh & 7 & 1,77 \\
\hline Pegawai kantoran & 108 & \multirow{3}{*}{$\begin{array}{l}27,34 \\
63,54 \\
7,09\end{array}$} \\
\hline Tidak bekerja & 251 & \\
\hline $\begin{array}{l}\text { Tidak ada } \\
\text { keterangan }\end{array}$ & 28 & \\
\hline \multicolumn{3}{|l|}{ Tempat Tinggal } \\
\hline DKI Jakarta & 337 & 85,32 \\
\hline Luar DKI Jakarta & 58 & 14,68 \\
\hline
\end{tabular}

Tabel 2. Pengelompokan Gigitan Hewan

\begin{tabular}{lcc}
\hline Hewan & $\begin{array}{c}\text { frekuensi } \\
\text { (n) }\end{array}$ & $\%$ \\
\hline $\begin{array}{l}\text { Anjing, Kucing } \\
\text { danKera (HPR) }\end{array}$ & 341 & 86,3 \\
$\begin{array}{l}\text { Lain-lain (Tikus, } \\
\text { Musang, Berang- } \\
\text { berang) Non HPR }\end{array}$ & 54 & 13,7 \\
\hline Jumlah & & \\
\hline
\end{tabular}

Mayoritas pasien kasus GHPR di RSPI Prof. Dr. Sulianti Saroso telah mendapatkan penanganan awal pasca gigitan HPR dengan segera yaitu mendapatkan Post-Exposure Prophylaxis Treatment dalam waktu $\leq$ 24 jam sebesar 83.3\% dan melengkapi kunjungan Post-Exposure Prophylaxis Treatment (PEP) hingga kunjungan VAR 3 sebesar 46,33\% (Tabel 4). 
Tabel 3.Karakteristik Kategori Risiko Luka dan Lokasi Gigitan

\begin{tabular}{|c|c|c|c|c|c|c|}
\hline \multirow{3}{*}{ Variabel } & \multicolumn{6}{|c|}{ GigitanHewan } \\
\hline & \multicolumn{2}{|c|}{$\begin{array}{c}\text { Anjing, Kucing, } \\
\text { Kera (HPR) }\end{array}$} & \multicolumn{2}{|c|}{$\begin{array}{l}\text { Lainnya (Tikus, } \\
\text { musang, berang- } \\
\text { berang) Non HPR }\end{array}$} & \multicolumn{2}{|c|}{ Total } \\
\hline & $\mathbf{n}$ & $\%$ & $\mathbf{n}$ & $\%$ & $\mathbf{n}$ & $\%$ \\
\hline \multicolumn{7}{|l|}{ Kategori Risiko Luka } \\
\hline Kategori $2^{a}$ & 275 & 69.6 & 21 & 5.3 & 296 & 74.9 \\
\hline Kategori $3^{b}$ & 66 & 16.7 & 33 & 8.4 & 99 & 25.1 \\
\hline \multicolumn{7}{|l|}{ Lokasi Gigitan } \\
\hline Area kepala & 19 & 4,81 & 3 & 0,76 & 22 & 5.6 \\
\hline $\begin{array}{l}\text { Area jari tangan atau } \\
\text { kaki }\end{array}$ & 37 & 9,37 & 30 & 7,59 & 67 & 17 \\
\hline Area badan & 10 & 2,53 & 0 & 0,00 & 10 & 2.5 \\
\hline Area tangan & 93 & 23,54 & 6 & 1,52 & 99 & 25 \\
\hline Area kaki & 172 & 43,54 & 15 & 3,80 & 187 & 47.4 \\
\hline Multi lokasi & 10 & 2,53 & 0 & 0,00 & 10 & 2.5 \\
\hline
\end{tabular}

Tabel 4. Karakteristik Waktu Mendapatkan PEP Awal dan Kunjungan PEP

\begin{tabular}{|c|c|c|c|c|c|c|}
\hline \multirow{3}{*}{ Variabel } & \multicolumn{6}{|c|}{ GigitanHewan } \\
\hline & \multicolumn{2}{|c|}{$\begin{array}{l}\text { Anjing, Kucing, } \\
\text { Kera (HPR) }\end{array}$} & \multicolumn{2}{|c|}{$\begin{array}{l}\text { Lainnya (Tikus, } \\
\text { musang, berang- } \\
\text { berang) Non HPR }\end{array}$} & \multicolumn{2}{|c|}{ Total } \\
\hline & $\mathbf{n}$ & $\%$ & $\mathbf{n}$ & $\%$ & $\mathbf{n}$ & $\%$ \\
\hline \multicolumn{7}{|l|}{ Waktu PEP } \\
\hline$\leq 24$ jam & 329 & 83.3 & 54 & 13.7 & 383 & 97 \\
\hline$>24 \mathrm{jam}$ & 12 & 3 & 0 & 0 & 12 & 3 \\
\hline \multicolumn{7}{|l|}{ Kunjungan PEP } \\
\hline VAR 1 & 110 & 27,85 & 19 & 4,81 & 129 & 32.6 \\
\hline VAR 2 & 44 & 11,14 & 15 & 3,80 & 59 & 14.9 \\
\hline VAR 3 & 183 & 46,33 & 18 & 4,56 & 201 & 51 \\
\hline Berulang $\left.{ }^{*}\right)$ & 4 & 1,01 & 2 & 0,51 & 6 & 1.5 \\
\hline
\end{tabular}

Keterangan :

*) Berulang merupakan pasien dengan gigitan oleh HPR lebih dari 1 kali dalam kurun waktu tertentu

\section{Pembahasan}

Mayoritas pasien kasus GHPR di RSPI Prof. Dr. Sulianti Saroso telah mendapatkan penanganan awal pasca gigitan HPR dengan segera yaitu mendapatkan Post-Exposure Prophylaxis Treatment dalam waktu $\leq$ 24 jam. Sejalan dengan penelitian Anandaraj dan Balu yang menyebutkan mayoritas korban gigitan hewan $(63,9 \%)$ melaporkan ke fasilitas kesehatan dalam waktu 6 jam setelah kejadian. ${ }^{(7)}$

Karakteristik berdasarkan pasien yang menyelesaikan jadwal PostExposure Prophylaxis Treatment (PEP) sebagian besar pasien gigitan hewan penular rabies di RSPI Prof. Dr. Sulianti Saroso melengkapi kunjungan Post-Exposure Prophylaxis Treatment (PEP) hingga kunjungan VAR 3. RSPI Prof. Dr. Sulianti Saroso sebagai rumah sakit rujukan tertier yang mendapatkan 
logistik VAR dari Kementerian Kesehatan RI.

Karakteristik pasien kasus gigitan hewandi RSPI Prof. Dr. Sulianti Saroso terbanyak ialah berjenis kelamin perempuan, hasil ini berbeda dengan beberapa penelitian yang menunjukan bahwa jumlah laki-laki lebih berisiko digigit anjing dari pada perempuan. Berbeda dengan penelitian Poorolajal dan Tenzi yang menunjukan bahwa mayoritas pasien kasus GHPR berjenis kelamin laki-laki. ${ }^{(8,9)}$ Pada kajian ini, jumlah pasien kasus gigitan hewan penular rabies lebih banyak perempuan daripada laki-laki kemungkinan disebabkan karena perempuan lebih banyak mencari pengobatan dari lakilaki.

Karakteristik pasien kasus GHPR di RSPI Prof. Dr. Sulianti Saroso mayoritas memiliki tingkat pendidikan menengah (SMP-SMA) dan tidak bekerja. Kemungkinan kelompok tidak bekerja didominasi oleh jenis kelamin perempuan berusia dewasa dalam hal ini ibu rumah tangga yang memiliki hewan peliharaan, tanpa menutup kemungkinan orang dewasa lainnya baik laki-laki atau perempuan yang memiliki mobilitas tinggi di luar rumah.

Berdasarkan karakteristik kelompok umur, kasus gigitan hewan mayoritas dewasa (18-60 tahun), kemungkinan karena pada usia dewasa lebih banyak kontak dengan hewan pengigit.Hasil kajian sesuai dengan penelitian Poorolajal bahwa mayoritas pasien kasus gigitan Anjing di Tehran Iran mayoritas kelompok umur 21-30 tahun dan di daerah perkotaan (urban area). ${ }^{(8)}$ Berbeda dengan penelitian Rothe, Mondal, $\mathrm{T} \mathrm{K}$ dan Prasanta RK menunjukan bahwa Animal Bite Victim (GHPR) cenderung menyeranganakanak. ${ }^{(10)(11)}$

Berdasarkan domisili mayoritas pasien dari wilayah DKI Jakarta. Hal ini dimungkinkan karena lokasi RSPI Prof. Dr. Sulianti Saroso yang berlokasi di provinsi DKI Jakarta. RSPI Prof. Dr. Sulianti Saroso mendukung program pemerintah dalam mempertahankan provinsi DKI Jakarta bebas rabies antara lain melalui Sistem Kewaspadaan Dini (SKD) kasus rabies serta melakukan perawatan sesuai petunjuk teknis penatalaksanaan kasus gigitan hewan penular rabies.

Sebagian besar pasien kasus gigitan hewan di RSPI Prof. Dr. Sulianti Saroso digigit oleh kelompok HPR jenis Anjing, Kucing dan Kera (AKK) sebanyak 341 kasus $(86,3 \%)$ dan kelompok hewan non HPR sebanyak 54 kasus (13,7\%). Mamalia pada dasarnya peka terhadap infeksi virus rabies tetapi terdapat urutan kepekaan dari berbagai spesies dari mamalia. Mamalia yang paling peka dan sering kali merupakan kasus 
rabies spontan adalah golongan anjing misalnya anjing domestik (anjing peliharaan), anjing hutan, serigala dan rubah. Beberapa spesies lain digolongkan ke dalam kepekaan sedang yaitu rakun, sigung, kelelawar sedangkan yang kurang kepekaanya adalah tupai. Manusia umumnya tertular karena gigitan HPR, karena virus rabies akan berada dalam kelenjar ludah hewan yang terinfeksi sekitar lima sampai tujuh hari sebelum gejala klinis. ${ }^{(12)}$

Selama ini di RSPI Prof. Dr. Sulianti Saroso pasien dengan diagnosa suspek Rabies/vulnus morsum/GHPR diberikan vaksin VAR pada pasien gigitan HPR dan diberikan juga pada pasien gigitan non HPR. Pemberian VAR diberikan lengkap sesuai jadwal hingga pasien menyelesaikan kunjungan tanpa ada tindak lanjut hasil laboratorium pemeriksaan spesimen otak HPR, dimana hasil pemeriksaan specimen otak HPR sangat berperan dalam pemberian dan pengendalian ketersediaan VAR yang merupakan obat program.

Perkembangan penyakit tergantung pada lokasi dan kehebatan luka gigitan, konsentrasi virus dalam gigitan, spesies hewan pembawa dan galur virus. Mortalitas tertinggi cenderung terjadi pada orang yang tergigit di daerah kepala atau muka (40\%-80\%) mortalitas menengah pada mereka yang digigit di tangan (15\%-40\%) dan terkecil jika digigit pada kaki (5\%$10 \%) .{ }^{(13)}$ Hasil penelitian menunjukkan, sebagian besar pasien pasien kasus GHPR di RSPI Prof. Dr. Sulianti Saroso mengalami luka gigitan diarea kaki dan memiliki kriteria luka gigitan kategori luka 2 (Luka risiko rendah). Sejalan dengan penelitian Tenzin yang menunjukan bahwa lokasi gigitan oleh HPR adalah kaki. (9) Penelitian Mondal TK dan Prasanta RK maupun DantasTorres et all yang menunjukan bahwa lokasi gigitan oleh HPR terbanyak pada tungkai bawah. ${ }^{(11)(14)}$

\section{Kesimpulan}

Gambaran karakteristik pasien rabies di RSPI Prof Dr. Sulianti Saroso adalah kasus gigitan hewan penular rabies (HPR) dengan luka kategori 2 dan dikaki. Vaksin VAR diberikan pada pasien gigitan HPR dan non HPR . Pada kasus gigitan HPR mayoritas diberikan $\leq 24$ jam dan pemberian sampai kunjungan VAR 3.

\section{Saran}

Perlu dilakukan sosialisasi dan edukasi kesehatan terkait HPR kepada masyarakat dan sosialisi penanganan luka dan pemberian VAR kepada tenaga medis di fasilitas tingkat 1 dan 2, serta perlu sosialisasi secara berkala 
kepada tenaga medis dan paramedis di RSPI Prof. Dr. Sulianti Saroso terkait tatalaksana kasus GHPR.

\section{Ucapan Terima Kasih}

Penulis mengucapkan terima kasih kepada Direktur Utama beserta seluruh jajaran Direksi RSPI Prof. Dr. Sulianti Saroso atas izin dan dukungan yang diberikan kepada tim kajiand an juga kepada Dr. Dwi Hapsari Tjandrarini, SKM, M.Kes dan tim atas bimbingan dan arahan kepada penulis dalam pelaksanaan kajian ini.

\section{Daftar Pustaka}

1. Pusdatin. Jangan Ada Lagi Kematian Akibat Rabies [Internet]. 2016 [cited 2017 Oct 10]. Available from: http://www.depkes.go.id/resourc es/download/pusdatin/infodatin/l nfodatin-Rabies-2016.pdf

2. World Health Organization (WHO). Rabies: Epidemiology and burden of disease [Internet]. 2017 [cited 2017 May 9]. Available from: http://www. who.int/rabies/epidemiology/en/

3. Kementerian Kesehatan RI. Profil kesehatan indonesia [Internet]. Jakarta; 2015 [cited 2018 Oct 2]. Available from: http://www.depkes.go.id/resourc es /download/pusdatin /profil- kesehatan- indonesia/profilkesehatan-Indonesia-2015

4. Ikatan Dokter Indonesia. Panduan Praktik Klinis Bagi Dokter di Fasilitas Pelayanan Kesehatan Primer. Jakarta: Kementrian Kesehatan RI; 2014.

5. Subdit Surveilans. Pedoman: Penyelidikan dan Penanggulangan Kejadian Luar Biasa Penyakit Menular dan Keracunan Pangan. Jakarta: Kementrian Kesehatan RI; 2017.

6. Kementerian Kesehatan RI. Buku Petunjuk Teknis Rabies Center. Jakarta: Kementrian Kesehatan Rl; 2017.

7. Anandaraj $\mathrm{R}$, Balu PS. Compliance to anti rabies vaccine and animal bite management practices in a rural area of Davangere, Karnataka , India. Int $\mathrm{J}$ Community Med Public Heal. 2016;3(1):170-3.

8. Poorolajal J, Babaee I, Yoosefi R, Farnoosh F. Animal bite and deficiencies in rabies postexposure prophylaxis in Tehran, Iran. Arch Iran Med. 2015;

9. Tenzin, Dhand NK, Gyeltshen T, Firestone S, Zangmo C, Dema $\mathrm{C}$, et al. Dog bites in humans and estimating human rabies mortality in rabies endemic areas of bhutan. PLoS Negl Trop Dis. 
2011;

10. Rothe K, Tsokos M, HanDrick W.

Animal and Human Bite Wounds.

Deutsches Arzteblatt

international. 2015.

11. Mondal T, Ray P. Care of animal bite victim in Community and in health care facility in a rural area of West Bengal . 2016;15(1):1-4.

12. Rahayu A. Rabies. J Ilm Kedokt Wijaya Kusuma. 2010;1(2).

13. Kerta Besung. INK, Suwiti N, Suatha I, Suastika P, Piraksa I, Setiasih NE. Vaksinasi, Edukasi Dan Eliminasi Anjing Liar Sebagai Usaha Percepatan Penanggulangan Penyakit Rabies Di Bali. Udayana Mengabdi. 2011;10(2):57-60.

14. Dantas-Torres F, De OliveiraFilho EF. Human exposure to potential rabies virus transmitters in Olinda, State of Pernambuco, between 2002 and 2006. Rev Soc Bras Med Trop. 2007; 